\title{
An Obligation to Represent and Disclose Material Facts as a Good Faith in Life Insurance Contract
}

\author{
Mokhamad Khoirul Huda \\ Faculty of Law, Hang Tuah University, \\ Surabaya, Indonesia
}

Doi: $10.2478 / \mathrm{mjss}-2018-0073$

\begin{abstract}
This study aims to analyze an obligation of explaining and revealing material facts and identify any kinds of violation of good faith in life insurance contract. It uses several approaches including statute approach, comparative approach, and conceptual approach. The result defines material facts as any kinds of facts the insurer needs in order to make decision whether accepting or objecting the possible risks assigned. The insurer needs to accurately and completely know the insured's personal data and medical records, including disease suffered, smoking habits, and even an extreme exercise habit such as paragliding. Kinds of violation probably done by the insured can be in the form of (1) misrepresentation, which includes giving incorrect statement but not intentionally conducted (i.e., innocent) and providing incorrect explanation intentionally (i.e., fraudulent) due to personal benefit; (2) non-disclosure, which includes neither revealing the facts nor telling any fundamental information other parties need to know, not due to deliberateness but rather probably due to ignorance or innocence, and intentionally hiding particular facts in order to get personal benefits (concealment).
\end{abstract}

Keywords: The insured, The insurer, life insurance, explaining material facts, revealing material facts

\section{Introduction}

Insurance or assurance is also known as verzekering or assurantie in Dutch term and as at-ta'min in Arabic (Dahlan,1996,p.138). E. R. Hardy Ivamy (1979, p.1) defined insurance contract as "a contract of insurance in the widest sense of term may be defined as a contract whereby one person, called the "Insurer", undertatakes, in return for the agreed consideration, called the "premium," to pay to another person, called the "Assured," a sum money, or its equivalent, on the happening of a specified event." Furthermore, Robert Merkin (2007, p.37) termed insurance as "a rare species of contract where both parties, the insured and the insurer, are under a mutual duty of utmost good faith"

Article 1 subsection 1 Law No. 40/ 2014 on Insurance defines insurance as a contract of two parties, including insurance company and policy holder, as a base in accepting premium for the insurance company as reward to: provide compensation for the insured or the policy holder due to detriment, damages, emerging cost, loss, or any responsibility that the insured/the policy holder may possibly be assigned for toward the third party due to uncertainty; or providing claim due to the insured's death or based on the insured's life with benefit which amount has been predetermined and/or based on the fund management.

Particularly for the definition of life insurance contract mentioned in article 1 Ordonnantie Op Het Levensverzekeringbedrijf S.1941-101. Pasal 1 tersebut mendefinisikan perjanjian asuransi jiwa sebagai berikutb: "overeenkomstem van levensverzekering de overeenkomsten tot het doon van geldelijke uitkeringen, tegen genot van premie en in verband met het leven of den dood van den 
menschs. Overeenkomsten van herverzekering daaronder begrepen, met dien verstande, dat overeenkomsten van ongevallenverzoring niet als overeenkomsten van levensverzekering worden berschouwd."

A good faith in life insurance contracts requires the insured to clearly and entirely represent and disclose any material facts dealing with the object insured (Merkin, 2007, p.37). The insured must provide any information the insurer needs on insured object, and thus, the insurer may see the weight of risk they possibly take over.

The insurer uses a reason that the insured does not hold a good faith in explaining and revealing the material facts dealing with the condition of the insured object by revoking the insurance (Huda,2016). For instance, when the insured fills the form of life insurance contract (SPAJ) and health certificate (SKK) in order to deal with a life insurance contract, a common question about whether or not the insured has smoked in last two years may usually be inserted on SKK. If, in fact, the insured is a smoker or has ever smoked in last two years, he/she should say "YES". In contrast, if the insured thinks that it does not really matter and feels good with his/her health or he/she just feels afraid that the premium may possibly increase, and thus he/she say "NO" on SKK, and when he/she has to make a claim of his/he insurance due to hospitalization, it may raise a problem for the insured. When claiming is conducted, the insurer may open the insured' documents; which one of those is SPAJ containing SKK. Unfortunately, the medical records show that the insured has ever been hospitalized due to heart disease caused by his/her smoking habit. In this case, the insurer may firmly assert that the claim is objected. Therefore, SPAJ must be filled well, honestly, and correctly.

Hence, an obligation to represent and disclose any material facts dealing with the insured personal data and medical records as a kind of good faith in life insurance contract is discussed here.

\section{Research Methodology}

Legal research (rechtsonderzoek) is a study to seek for resolutions of legal issues by providing prescription on studied issues (Marzuki 2005, p.35). Several approaches including statute approach, comparative approach, and conceptual approach (Ibrahim, 2008, p.310) are used here. The legal data derives from primary and secondary legal data. The data is analyzed in qualitative manner according to the problem. It is a descriptive analysis consisting of displaying, analyzing, estimating, interpreting, and evaluating data. A theoretical analysis is then conducted on those legal data in order to find, see, and describe the obligation of explaining and revealing any material facts needed as a kind of good faith in a life insurance contract.

\section{Results and Discussion}

\subsection{The Provision of Good Faith in Life Insurance Contract}

Article 251 Weboek van Kophandel sets an obligation to have a good faith known as "uberrima fides" or "uberrima fidae"(Khairandy, 2004,p.13). Uberrima fides or uberrima fidei, derived from Latin, are defined as:"a phrase used to express the perfect good faith, concealing nothing, with which a contract must be made; for example in the case of insurance, the insured must observe the most perfect good faith towards the insurer" (Robinson et.al, 1998,p. 11).

Following Uli Foerstl, the word fides is derived from "the name of the Roman goddess fides, the deification of good faith and honesty, the oath, and that one must keep one's word." the essence of bona fides is fides. Fides is developed as procedural standards of contract, known as exceptio doli (Foerstl, 2005, p. ii).

Similarly, article 17 Marine Insurance Act 1906 mentions: "a contract of marine insurance is a contract based upon the utmost good faith, and, if the utmost good faith be not observed by either party, the contract may be avoided by the other party. Lord Mansfield asserted how important the principle of utmost good faith is in an insurance contract in Britain as follows. 
"Insurance is a contract upon speculation. The special facts, upon which the contingent chance is to be computed, lie most commonly in the knowledge of the insured only; the under-writer trusts to his representation, and proceeds upon confidence that he does not keep back any circumstances in his knowledge, to mislead the under-writer into a belief that the circumstances does not exist, and to induce him to estimate the risque as if it did not exist. The keeping back such circumstance is a fraud, and therefore the policy is void... The governing principle is applicable to all contracts and dealings. Good faith forbids either party by concealing what he privately knows, to draw the other into a bargain, from his ignorance of that fact and his believing the contrary ..."(Feng, 2008).

Susan Hodges argued, "the principle applies to all policies whatever the risk or the subjectmatter insured"(Hodge, 2004, p.83).

Lord Jauncey, House of Lord dalam kasus Banque Financiere v. Skandia (UK) Insurance Co. Ltd also suggested that an obligation to do "utmost good faith" and reveal any material facts were equally applied for the both parties, the insured and the insurer. He argued that an obligation of having a good faith is assigned to both the insured and the insurer as follows.

"The duty of disclosure arises because the facts relevant to the estimation of the risk are most likely to be within the knowledge of the insured and the insurer therefore has to rely upon him to disclose matters material to that risk. The duty extends to the insurer as well as to the insured: Carter v.Boehm. The duty is, however, limited to facts which are material to the risk insured, that is to say facts which would influence a prudent insurer in deciding whether to accept the risk and, if so, upon what terms and a prudent insured in entering into the contract the terms proposed by the insurer. Thus any facts which would increase the risk should be disclosed by the insured and any facts known to the insurer but not the insured, which would reduce the risk, should be disclosed by the insurer, There is, in general, no obligation to disclose supervening facts which come to the knowledge of either party after conclusion of the contract... Although there have been no reported cases involving the failure or an insurer to disclose material facts to an insured the example given by Lord Mansfield in Carter v.Boehm is of an insure who insured a ship for a voyage knowing that she had already arriver." (Robinson et.al, 1998, p. 11).

This was used as a base for Lord Mansfield (1766) to make a judgment for Carter v. Boehm case, that an insurance contract is based on utmost good faith.

The legal position of Carter $v$ Boehm case (1766.) was as follows.

\begin{abstract}
"Background to Carter v Boehm: Carter was the Governor of Fort Marlborough, which was built by the British East India Company in Sumatra, Indonesia. Carter took out an insurance policy with Mr Boehm against the fort being taken by a foreign enemy. A witness, Captain Tryon, testified that Carter knew that the fort had been built to resist attacks from natives, but not European enemies, and the French were likely to attack. The French did attack, and Boehm refused to fulfill the insurance claim. Carter sued, but failed to have the claim paid." (Manning,2010,p.5; Lowry; 2009).
\end{abstract}

The most obvious manifestation on an obligation of having a good faith is an obligation to represent and disclose any material facts. (representation and disclosure of material facts). The plausible reason of such disclosure can be found in Lord Mansfield CJ's statement in Carter $v$ Boehm case. Basically, the insured commonly know any relevant information dealing with insured risks, and thus, it is used as a consideration for the insurer to take over the risk.

In the context of life insurance contract, the insured is considered knowing more about the object possibly insured, including the medical record. Thus, he/she must entirely present and disclose any material facts related to the insured object accurately, whether it is asked or not, such as particular illness he/she has ever suffered from, smoking habits, and even particular extreme exercise habit like rock climbing, paragliding, and diving.

All the material facts is appraised by the insurer, so that it may impact on the insurer's decision whether accepting or objecting any possible risk he may take over. Thus, it is a must for the insured to meet underwriting standart (Chumaida, 2013, p.144) and a request for closure will be accepted with a standard premium, however, if the prospective insured may not comply with the underwriting standart, the underwriting may object the contract, or accept it but with higher premium. 


\subsection{The Meaning of Material Facts in Life Insurance Contract}

Basically, before making a deal in a life insurance contract, the insured is required to represent (duty of representation) and disclose (duty of disclosure) any material facts related to the insured object.

The requirement to represent and disclose any material facts is set under the article 251 Wetboek van Kophandel that "Alle verkeerde of onwaarachtige opgave, of alle verwijging van aan den verzekerde bekende omstandigheden, hoezeer te goeder trouw aan diens ziijde hebbende plaats gehad, welke van dien aard zijn, dat de overeekomst niet, of niet onder dezelfde voorwaarden, zoude zijn gesloten, indien de verzekeraar van den waren staat der zaak had kennis gredragen, maakt de verzekering nietig."

Material facts is any facts which may influence the insurer's consideration whether or not the insurer closes the insurance, or closes the insurance over the insured object but with particular conditions or extraordinary premium (Purba, 1995, p.48.).

Material facts, in The Lectric Law Lirary's Lexication, is defined as: "a fact that would be important to a reasonable person deciding whether to engage or not to engage in a particular transaction; an important fact as distinguished from un important or trivial detail. The Word material means that the subject matter of which the statement (or concealment) related to a factor circumstance which would be important to the decision to be made a distinguished from insignificant, trivial or unimportant detail. A material fact is one which might affect the outcome of the case under government law."

Fakta material dalam Cila sebagai: "Every circumstance or information, which would influence the judgement of a prudent insurer in assessing the risk or those circumstances which influence the insurer decision to accept or refuse the risk or which effect the fixing of the premium or the terms and conditions of the contract must be disclosed."

Similarly, it is set under the article 7.17.928.1 Niewe Burgelijke wet Boek Netherland that requires the insured to represent all facts of which he/she is or ought to be aware and on which, as he knows or ought to understand, the insurer makes decision.

Article 7.17.1.928 subsection (4) Niewe Burglerlijke Wet Boek mentioned:

"The disclosure obligation does not extend to facts of which the insurer is already or ought to be aware, or to facts which would not have resulted in a less favourable decision for the policyholder. However, a policyholder or a third person referred to in paragraph 2 or paragraph 3, who has given an incorrect or incomplete answer to a specific question on the matter may not claim that the insurer was already or ought to have been aware of specific facts. The disclosure obligation shall also not extend to facts for which no medical examination may be performed and on which no questions may be raised pursuant to Articles 4 to 6, inclusive, of the Wet op de medische keuringen (Medical Examinations Act) in the instances mentioned therein."

Article 7.17.1.928 subsection (6) NBW also mentions about questionnaires (the certificate of Life Insurance Contract [SPAJ] and Medical Records [SKK]) the insured makes as follows.

"When the insurance is concluded on the basis of a questionnaire drafted by the insurer, the insurer may not rely on the fact that questions were not answered or that facts in respect of which no question was raised were not disclosed or that the answer to a question couched in general terms was incomplete, unless there was intent to mislead the insurer."

However, Marine Insurance Act 1906 defined material facts as: (1)... every material circumstance which is known to the assured, and the assured is deemed to know every circumstance which, in the ordinary course of business, ought to be known by him. If the assured fails to make such disclosure, the insurer may avoid the contract. (2)Every circumstance is material which would influence the judgment of a prudent insurer in fixing the premium, or determining whether he will take the risk.

In providing material facts, the insured must have insight into the insured object. Following Turner, it is classified into five category, including: a). Knowledge of facts of public notoriety; b). Facts the party should have knowledge about in the course of his business; c). Facts subject to 
actual knowledge by an agent; d). Facts being a natural extension of facts of actual knowledge); and e). Presumed knowledge by law (Gjelsten, 2007).

Determining whether a fact in life insurance is material or immaterial is difficult to do. However, what material facts point to includes: a). Facts that show higher risks in life insurance contract such as risky job (e.g., nurse or midwife susceptible to illness derived from patients); b). External factors which make the risk higher than it is supposed to be, such as: extreme hobbies \{e.g., paragliding, diving, etc.); c). Facts making the loss higher than it is expected to be (e.g., smoker, alcoholic); d). The track of life insurance (e.g., details of compensation and previous claims on which the previous insurance company has ever objected the insured object or any other specific condition the current insurance company takes over); and e) other life insurance contracts the insured may have (Chai, 1993, Bahrun, 1988: 16).

In regard to the kinds of material facts within life insurance contracts, they are classified into two categories, including physical hazard and moral hazard. Physical hazard points to all physical factors of the insured such as ages, residence, daily habits, and hobbies he/she has. Moral hazard relates to the insured's character and moral traits. It is like a claim experience or dishonesty which may create a claim for a policy or the insured has ever been legally charged.

In addition, details of material facts in life insurance involve: a). Data from prospective insurers that consists of complete name, place of birth, age, gender, religion, education, occupation, occupation field, and position or grade, instance and tax ID number; b). Data of the insured's medical records and hobbies, including: smoking, weight of birth (in particular to children), symptoms ever examined/checked up/suffered from/diagnosed/cured from/suggested or hospitalized/undergone surgery/suggested to have medical advices/had ever had medical advices or reconciled to the specialist for particular disorder related to certain illness like myopia, ears, hypertension, diabetes, tumor/neoplasm, allergy, indigestion and other particular illness; c). Data of the insured if he/she has ever been examined or suggested to do: a check-up for heart/blood/ urine/roentgen/USG/CT-Scan/Biopsy/supporting medical check-up or other diagnostic attempts (anything, when, why, and the result of the examination); d). Data of the insured's family members (whether alive or died) that have ever suffered from coroner heart/stroke/diabetes mellitus/cancer/ and any other diseases; e). Data of the prospective insured in which he/she has ever used drugs or other addictive substances; f) Data of the insured's hobbies or suddenly doing a high-risk activity or even still active in high-risk job such as diving, rock climbing, paragliding, race, mining, sailing, flight, and marshal.

A requirement to represent and disclose material facts is applied: 1). since a negotiation of a life insurance contract is conducted up to dealing with the contract, on which the both parties deal with the contract; 2) when the contract is extended; and 3) when any related changes are determined on the life insurance contract (Danarti, 2016).

Cris Parsons, David Green and Mike Mead argued that the period of time to provide fundamental material facts are varied, depending on particular conditions such as: a) Common Law, beginning from the negotiation of a contract until a deal is created by the both parties; b) Contractual duty, requiring to conceal nothing about any crucial facts as long as the contract is applied and providing rights for the insurer to object any changes possibly happen; c) Position at renewal, requiring to disclose all crucial facts depending on the kinds of contract. This includes: First, long-term business, in terms of life insurance and health insurance, the insurer is required to accept the premium of contract extension if the insured is willing to extend the insurance contract and he/she does not have to disclose any material facts on that extension. Second, other business, for other kinds of insurance, it needs the insurer's acceptance for extending the contract by redisclosing all important facts. Third, alteration to the contract, when it comes to changes on life insurance contract that involves the increasing value of insurance or the change dealing with the description of the insured object, an obligation to disclose all important facts is required. This provision is applied to the long-term business and other business as well (Wardana,2009,p.35).

\subsection{Violation of Obligation to Represent and Disclose Material Facts in Life Insurance Contract}

An Obligation to represent and disclose material facts is applied since negotiating up to dealing the 
contract. The Supreme Court of Canada, in a case of Canadian Indemnity Co. v. Canadian JohnsManville Co. showed how crucial the insurer's insight is, as follows.

"Where it was held that an insurer could not use his own lack of due diligence as a basis for avoiding a policy. The Court held that if an insurer does not have the requisite degree of knowledge prior to considering a particular risk, then it must acquire that knowledge by means of inquiry or investigation."

This is asserted by the Supreme Court in Co-operator General Insurance Co v. Porteous that mentioned, "The duty to exercise the utmost good faith not only exists at the time when the contract is made but throughout the dealings between the parties both before and after the loss."

Furthermore, the law of contract in Britain defines the term 'representation' as "a statement of fact made by one person to another which influences the other in making a contract with the representer, but which is not necessarily a term of that contract (Wincup, 2001, p.277; Wise, 2009). If such statement is wrong, it is considered as a misinterpretation. Using that definition, three conditions are identified, as follow:1) a statement of facts; 2) made by one person to another; and 3 ) influencing another party in making a contract.

Moreover, kinds of violation on contract are classified into two category, as follows.

a. Not providing any representation (misinterpretation) that involves:

1) Providing incorrect statement or representation but not due to a deliberateness (innocent)

It may happen when the insured does not disclose material facts on the insured object prior to the acceptance of his/her insurance request (SPAJ). Material facts is important information that determine whether an insurance request is objected or accepted but with particular condition and different premium (Kronman, 1978). Not all information is considered material. However, it is not easy to see whether or not particular information is material. Thus, the insured is required to disclose all information dealing with the insured object he/she is or supposed to be aware of. Nevertheless, violation may happen due to several reasons, such as: disclosing incomplete or wrong information; concealing information, deliberately providing incorrect information (Yeasmeen, 2015; Kirby, 2011 ).

Andrian Chandler dan Ian Brown (2013) classified misinterpretation into two categories: innocent misinterpretation and negligence misinterpretation. However, Ewan McEndrick (2013) classified misinterpretation into three categories: a)Fraudulent misrepresentation, b) Negligent misrepresentation; and c)Innocent misrepresentation.

Representing information is commonly conducted by filling a form of insurance contract/ SPAJ, containing a form of medical record (SKK) within, provided by the insurer. In particular, the insured is frequently warned to disclose all necessary information he/she knows for the contract. From Juridical view, the court judges are considered as authorized parties that consider whether or not the insured's information is material (Dobby, 1981, p.149; Greene, 1983).

Information considered material is information the insured is or supposed to aware of about the insured object and it may influence the insurer's attitude in whether or not accepting the insured object. In life insurance, SPAJ and SKK can be in the form of blanks of personal data, financial data, employment data, and other forms of data the insurer needs as a base of insurance (Sendra, 2004, p.94).

An individual may represent facts with full of conviction and expectation that those are right, but however, those are in fact wrong. For instance, the prospective insured has ever been hospitalized due to fever; however, the cause of fever is unidentified yet, thus the insured should note on the policy that he/she ever got fever, in case the cause of fever may possibly be dangerous for the insured.

2) Intentionally Representing Incorrect Statement for Personal Benefit (Intentional/fraudulent)

If the prospective insured, in filling the form of an insurance request, deliberately 
conceals material information about the insured object toward the insurer, the contract may become null. An intentional error may occur when the proposer deliberately distorts the information he knows in order to deceive the insurance company. One instance of ways to deal with insurance contract or have premium alleviation is that the prospective insured, in filling his medical records within SPAJ, notes that he smokes 5 cigarettes a day but, in fact, he takes 30 cigarettes a day. Misinforming may influence the insurer's decision.

In regard to information delivery, both innocent and concealment link to misinformation. However, the innocent unintentionally misrepresents the information, while the concealment deliberately misrepresents the information in order to deceive the insurer (Dobbyin, 1981, p.149.).

b. Not disclosing any material facts, including:

1) Not disclosing or informing any facts another party needs, not due to deliberateness, but rather likely due to innocence.

This is apparent when an individual does not realize the facts or when he realizes the facts but does not know their significance. For instance, the insured suffers from rheumatic fever since kids but he does not think that it matters so that he does not disclose the fact while filling the form of insurance request. He does not realize that someone who often gets fever since kids is considered susceptible to hearth disease when he is old.

2) Intentionally Concealing Facts for Personal Benefits (Intentional/concealment).

Misrepresenting information may happen due to its delivery, content, or materials from misinformation. Furthermore, it is intentionally done in order to deceive the insurer so that the life insurance contract can be closed, things the insurer may not consider when he knows the true facts. For instance, the prospective insured has a high-risk extreme hobby such as rock climbing or paragliding, however, the prospective insured does not note his extreme hobby on SPAJ.

\section{Conclusion}

Life insurance contract is based on the principle of good faith. The insured's good faith points to an obligation of representing and disclosing all material facts related to his personal data and medical records. A fact is considered material (material facts) if the representation or concealment of a fact may influence the insurer to make decision whether accepting or objecting the possible risk he may take over. Thus, material facts are not solely seen based on the types, but also the substance which the insured considers important. Violation on material facts involves misrepresenting and concealing information the insured actually knows, which may fail the life insurance contract.

\section{References}

Baharum, Mohd Ali. (1988). Misrepresentation: a Study of English and Islamic Contract Law. Kualalumpur: AlRahmaniah.

Chumaida, Zahry Vandawati. (2013). Prinsip Iktikad Baik dan Perlindungan Tertanggung Pada Perjanjian Asuransi Jiwa. Disertasi. Program Doktor IImu Hukum Universitas Airlangga: Surabaya.

Dahlan, Ahmad Aziz et.al. (1996). Ensiklopedi Hukum Islam. Jakarta: Ichtiar baru van Hoeve.

Danarti, Dessy. (2011). Jurus Pintar Asuransi: Agar Tenang, Aman dan Nyaman. Yogyakarta: Andi Offeset.

Dauglas F. Robinson Q.C . and John Neocleous. (1998). "Issues of Insurance Fraud". International Symposium on The Prevention \& Control of Financial Fraud, Beijing, 19-22, October.

Dobbyn, John F. (1981). Insurance Law. St. Paul Minn: West Publishing Co.

Feng, Shi. (2008). Utmost Good Faith in Marine Insurance: a Comparative Study of English and Chinese Maritem Law. Plymouth Law Review. 1:154-160.

Huda, Mokhamad Khoirul. (2017). Good Faith in Life Insurance Contract by Indonesian Court. Hasanudin Law Review. 3(1):49-58. DOI.10.20956/halrev.v311.1046.

Huda, Mokhamad Khoirul et.al. (2016). "The Nature of the Contract of Life Insurance Agency after Enactment of the Act Number 40 of 2014 on Insurance". Journal of Advanced Research in Law and Economics. 7(5):1037-1-41. 
Hodges, Susan. (2004). Law of Marine Insurance. London: Calvendish Publishing Limited.

Ibrahim, Johnny Ibrahim.(2008). Teori \& Metodologi Penelitian Hukum Normatif. Malang: Bayumedia Publishing. Ivamy, Hardy. E.R. (1979). General Principles of Insurance Law. Fourt Edition.London: Buttersworths.

Khairandy, Ridwan. (2004). Iktikad Baik dalam Kebebasan Berkontrak. Jakarta: Universitas Indonesia.

Kirby. Michael. ( 2011 ). Insurance Contract Law Reform - 30 Years On. Insurance Law Journal. 1: 2753

Kronman, Anthony T. (1978). Mistake, Disclosure, Information, and The Law of Contract. Journal of Legal Studies. 7 (1):1-19.

Lowry, John. ( 2009 ). Whither the Duty of Good Faith in UK Insurance Contract. Connecticut Insurance Law Journal. 16 (1):97-156.

Manning, Alan. (2010). Manning Six Principles of General Insurance: A Comprehensive Guide to Utmost Good Faith, Indemnity, Subrogation, Contribution, Insurable Interest \& Proximate Cause, (Victoria: Mannings of Melbourne Pty Ltd, Camberwell.

Marzuki, Peter Mahmud Marzuki. (2005). Penelitian Hukum. Jakarta: Kencana Prenada Media Group.

Purba, Radiks. (1995).Memahami Asuransi di Indonesia.Jakarta: Pustaka Binaman Pressindo.

Purwosutjipto, H.M.N. (1990). Pengertian Pokok Hukum Dagang: Hukum Pertanggungan. Jakarta: Djambatan.

Poedjosoebroto, Santoso. (1969). Beberapa Aspek tentang Hukum Pertanggungan Jiwa di Indonesia. Jakarta: Bhratara.

Merkin, Robert. (2007). Practical Insurance Guides: Insurance Law-An Introduction. London: Informa.

Robinson Q.C.Dauglas F. and John Neocleous.(1998). Issues of Insurance Fraud, International Symposium on The Prevention \& Control of Financial Fraud, Beijing, 19-22, Oktober.

Sendra, Ketut. (2004). Konsep dan Penerapan Asuransi Jiwa Unitlink Proteksi Sekaligus Investasi; Buku Penuntun Agen dan Konsultan Keuangan Unit Link untuk Sukses Meraih Lisensi. Yogyakarta; Bayu Indra Grafika.

Yeasmeen, Nargis. ( 2015). Consequences of Non-Disclosure in the Contract of Insurance. IOSR Journal of Business and Management. 17 (6):29-36.

Wardana, Kun Wahyu. (2009). Hukum Asuransi: Proteksi Kecelakaan Transportasi. Bandung: Mandar Maju.

Wise, Robert.K et.all. (2009). Of Lies and Disclimers-Contracting Araund Fraud Under Texas Law. ST. Mary's Law Journal. 41(119):119-176.

Wincup, Michael H. (2001). Contract Law and Practice. London: Hague. 